\title{
Apportionment of damages for contributory negligence: a fixed or discretionary approach?
}

\author{
James Goudkamp* \\ Keble College, Oxford
}

In most of the common-law world, legislation provides for damages to be apportioned where the claimant is guilty of contributory negligence. This legislation gives judges considerable latitude to determine the extent to which damages should be diminished for contributory negligence. It imposes what will be called a system of 'discretionary apportionment'. This paper draws attention to the fact that, although most common-law jurisdictions are, by virtue of their apportionment legislation, in the thrall of the paradigm of discretionary apportionment, there are many, varied departures from this paradigm. This paper classifies these departures (which will be called 'fixed apportionment rules'), emphasises that they conflict with the apportionment legislation and considers how the conflicts ought to be resolved. An important conclusion reached is that it can plausibly be argued that the landmark decision in Froom $\mathrm{v}$ Butcher, at least as it has been understood in subsequent cases, was decided per incuriam. Froom sits uncomfortably with the apportionment legislation. Attention is then turned to the arguments for and against a discretionary system of apportionment as opposed to a system that incorporates more fixed apportionment rules. It is contended that much stands to be gained from introducing more fixed apportionment rules.

James Goudkamp, Keble College, Oxford OX1 3PG, UK. Email: james.goudkamp@law.ox.ac.uk

\section{INTRODUCTION}

The doctrine of contributory negligence is one of the most important parts of the law of torts. ${ }^{1}$ Few other rules are in issue in tort litigation with such regularity. ${ }^{2}$

* Fellow, Keble College, Oxford; Associate Professor, Oxford Law Faculty. I am grateful to John Murphy, Donal Nolan and Prince Saprai for their helpful comments on early drafts of this paper. I am also indebted to the participants in the University of Sydney Forum on Apportionment and the Attribution of Liability (especially to Peter Cane), the Moral Values and Private Law III workshop at King's College London (particularly to Andrew Dyson, John Goldberg, Victor Tadros and Benjamin Zipursky) and the tort strand of the Society of Legal Scholars' Annual Conference 2014 (especially to Jenny Steele and Stephen Todd). Many thanks are due to Ellen Bublick for reviewing my use of US sources and also to Eleanor Mitchell for her research assistance. Finally, I wish to record the debt that I owe to the anonymous referees, for putting a range of suggestions to me. These suggestions enabled me to make several significant adjustments to the analysis.

1. " "Contributory negligence" ... is raised very frequently, and has a great impact on the operation of the law': T Weir An Introduction to Tort Law (Oxford: Clarendon Press, 2nd edn, 2006) p 123. 'Contributory negligence is a core element in tort law in England (and other 


\section{Legal Studies}

For one reason or another, however, it has attracted little scholarly interest, and certainly much less than it deserves. Given this lack of academic attention, it is perhaps unsurprising that some striking features of the doctrine have gone essentially unnoticed. This paper begins by noting two such features. The first is that the law governing the doctrine has in many jurisdictions remained essentially frozen following the passage of apportionment legislation. In Britain, the relevant rules have hardly changed at all since the Law Reform (Contributory Negligence) Act 1945 was enacted. ${ }^{3}$ Parliament has scarcely touched this Act since passing it, and the courts have made relatively few (and certainly no radical) changes to the law in this area. Generally speaking, the description of the law regarding contributory negligence offered by Glanville Williams in 1951 in his magisterial treatise Joint Torts and Contributory Negligence $e^{4}$ is as accurate today as when it was written. ${ }^{5}$ The law in Canada has similarly remained largely stationary since the introduction of apportionment legislation, which occurred in most of Canada in the 1920s and 1930s. The situation in Australia has been more fluid. Decades after apportionment legislation was enacted in Australia, several legislatures provided for, among other things, presumptions of contributory negligence where the claimant engages in specified behaviour ${ }^{6}$ and rules that require the courts to reduce damages by a minimum ${ }^{7}$ or fixed percentage ${ }^{8}$ in certain situations. However, these changes are hardly revolutionary. In summary, since the coming of apportionment, the law governing the doctrine of contributory negligence has generally been extremely stable throughout the common-law world.

The second striking feature of the law regarding contributory negligence that has passed largely unnoticed is that differences in the law between the major common-law systems are minimal. For example, the core rules that govern the doctrine of contributory negligence in Australia, Britain and Canada are essentially identical. These rules, stated very simply, are as follows: (1) a claimant is guilty of contributory negligence if he fails to take reasonable care of his own safety and that failure is causally related

common-law countries)': WVH Rogers 'Contributory negligence under English law' in U Magnus and M Martín-Casals (eds) Unification of Tort Law: Contributory Negligence (The Hague: Kluwer, 2004) p 57.

2. '[It] is used on a daily basis. It is applied regularly by courts, but it is used much more frequently by parties (including of course insurers) negotiating settlements': J Steele 'Law Reform (Contributory Negligence) Act 1945: collisions of a different sort' in TT Arvind and J Steele (eds) Tort Law and the Legislature: Common Law, Statute and the Dynamics of Legal Change (Oxford: Hart Publishing, 2013) p 165. '[I]t is extensively used': D Harris 'Claims for damages: negotiating, settling or abandoning' in D Harris et al (eds) Compensation and Support for Illness and Injury (Oxford: Clarendon Press, 1984) p 91.

3. Most of the Act extends to Scotland. The Act does not extend to Northern Ireland, which has its own legislation: Law Reform (Miscellaneous Provisions) Act (Northern Ireland) 1948. The statute in Northern Ireland is extremely similar to the British legislation.

4. GL Williams Joints Torts and Contributory Negligence: A Study of Concurrent Fault in Great Britain, Ireland and the Common-Law Dominions (London: Stevens \& Sons, 1951).

5. 'Glanville Williams['s] . . . text on contributory negligence ... remains, arguably, the best analysis available today' of the law in this area: Chae v Min [2001] ABQB 1071 at [14]. 'Although now over 50 years old, G Williams Joint Torts and Contributory Negligence (London: Stevens \& Sons, 1951) is still the leading treatment': Rogers, above n 1, p 57, fn 1.

6. See eg Motor Accidents Compensation Act 1999 (NSW), s 138(2); Civil Liability Act 2002 (NSW), s 50(3).

7. See section 4(b) below.

8. See section 4(a)(ii) below. 
to his damage $;^{9}(2)$ if the claimant is guilty of contributory negligence, his action will not be defeated on account of that contributory negligence, but his damages must be reduced; ${ }^{10}$ and (3) the reduction must be 'just and equitable', and this is determined by having regard to the relative blameworthiness of the parties and the causal potency of their acts. ${ }^{11}$ The situation in the USA disrupts this harmonious picture. Some jurisdictions in the USA embrace 'pure comparative responsibility' regimes, which consist of rules that are materially identical to those that have just been described. However, a majority of jurisdictions have 'modified comparative responsibility' systems, in which contributory negligence by the claimant is fatal to his action if his share of the responsibility for his damage reaches a certain level (usually 51\%). ${ }^{12}$ Accordingly, rule (2) above is not fully implemented in the USA. However, notwithstanding the diversity of approaches in the USA, it is generally true to say that, in most of the common-law world, there is a high degree of uniformity in the law regarding contributory negligence.

These two features of the doctrine of contributory negligence - minimal evolution in the law subsequent to the introduction of apportionment legislation and a high degree of uniformity among common-law jurisdictions - might be thought to suggest that there is widespread satisfaction with the law in this connection. This perception is arguably reinforced by the fact that, in most of the common-law world, academic engagement with the doctrine is virtually non-existent. This is particularly true in Australia, Britain and Canada, where descriptions of the doctrine offered in textbooks are uniformly bland and prosaic ${ }^{13}$ and journal papers concerning it are almost entirely absent. ${ }^{14}$ Difficult questions are simply not being asked in relation to the doctrine. This paper tackles one such question: to what extent should the apportionment of damages for contributory negligence be left to judicial discretion? In other words, should judges have essentially free rein to determine the appropriate discount or should rules that specify ex ante the discount to be applied ('fixed apportionment rules') be adopted? This question appears not to have been previously considered, at least not

9. 'In order to establish the defence of contributory negligence, the defendant must prove, first, that the plaintiff failed to take "ordinary care for himself," or, in other words, such care as a reasonable man would take for his own safety, and secondly, that his failure to take care was a contributory cause of the accident': Lewis v Denye [1939] 1 KB 540 (CA) 554 (Du Parcq LJ). 10. If the claimant is guilty of contributory negligence, the courts have no discretion not to reduce damages: Boothman v British Northrop Ltd [1972] 13 KIR 112 (CA) 121-122; Bagder v Ministry of Defence [2005] EWHC 2941 (QB); [2006] 3 All ER 173 at [15].

11. Stapley $v$ Gypsum Mines Ltd [1953] AC 663 (HL) 682; Podredersek $v$ Australian Iron and Steel Pty Ltd (1985) 59 ALJR 492 (HCA) 494. The position in Canada might be different in this connection. Consider Cempel v Harrison Hot Springs Hotel Ltd (1997) 43 BCLR (3d) 219 at [19], where it is opined that the parties' fault only should be compared. See also Heller $v$ Martens [2002] ABCA 122; (2002) 4 Alta LR (4th) 51.

12. Regarding the jurisdictions that accept pure and modified comparative responsibility, and the small number of jurisdictions that withhold apportionment altogether, see the Restatement (Third) Torts: Apportionment of Liability $\$ 7 \mathrm{cmt}$ a.

13. In 1974 one writer justifiably complained that 'In England most standard textbooks have little or nothing to say' about contributory negligence: JC Hicks 'Seat belts and crash helmets' (1974) 37 Mod L Rev 308 at 313. This complaint remains valid today.

14. For rare exceptions, see G Williams 'The Law Reform (Contributory Negligence) Act 1945' (1946) 9 Mod L Rev 105; Lord Wright 'Contributory negligence' (1950) 13 Mod L Rev 2; Hicks, above n 13; N Gravells 'Three heads of contributory negligence' (1977) 93 Law Q Rev 581. 
directly and at length. Certainly, no mention of it is made by Glanville Williams in his work on contributory negligence, ${ }^{15}$ which remains the most comprehensive treatment of the subject by far.

This paper unfolds as follows. Section 2 explains what the concepts of discretionary apportionment and fixed apportionment entail. In section 3, it is noted that the British apportionment provision (which has served as a model in many other jurisdictions), embraces discretionary apportionment. It is a 'discretionary apportionment rule'. Section 4 notes that, despite the acceptance of discretionary apportionment by the apportionment legislation, many fixed apportionment rules have infiltrated the law in all of the major common-law jurisdictions. Section 5 stresses the incompatibility of discretionary apportionment rules and fixed apportionment rules and discusses how conflicts between these rules should be resolved. Section 6 examines the case for and against discretionary and fixed apportionment respectively and concludes that it would be better if the law was tilted more in favour of fixed apportionment than it is at present. Section 7 considers how, precisely, the law should be shifted in the direction of fixed apportionment. Section 8 addresses some implications of the analysis for the doctrine of contribution. The main conclusions are summarised in section 9 .

\section{THE CONCEPTS DISTINGUISHED}

In a legal system that provides for damages to be apportioned for contributory negligence, a distinction can be drawn between two general approaches to apportioning damages based on how free judges are to determine the amount by which damages are to be discounted. These approaches will be called 'discretionary apportionment' and 'fixed apportionment'. Under the paradigm of discretionary apportionment, judges enjoy essentially absolute freedom to decide the discount. They can take account of whatever facts of a given case that they feel are important (and ignore facts that they think are unimportant). Because of the freedom that discretionary apportionment affords judges to decide the discount, factually similar cases might attract rather different discounts, and the same or a similar discount might be applied in factually dissimilar cases.

By contrast, the paradigm of fixed apportionment entails apportioning damages in some ex-ante way. Judicial freedom to determine the discount for contributory negligence is restricted. Under a fixed apportionment regime, categories of case are identified and cases that fall within a given category are handled in the same fashion. Thus, in a regime of fixed apportionment two cases that fall within the same category may be handled in a like way irrespective of any differences between them. The most obvious way of isolating a category of case for the purpose of applying a fixed apportionment rule to cases that fall within it is by reference to particular acts of contributory negligence, such as failing to wear a seat belt or omitting to use a safety helmet.

The difference between discretionary apportionment and fixed apportionment is not as stark as it may initially seem. They represent poles on a spectrum rather than a digital choice. For one thing, even under an extreme system of discretionary apportionment, judges do not have total freedom to impose a given discount. The freedom given to judges in a discretionary apportionment system can never be total because

15. Williams, above $n 4$. 
judges, by virtue of their office, are subject to certain constraints. ${ }^{16}$ Judges must act judicially, and this includes an obligation to produce outcomes that are at least roughly consistent with outcomes in other factually similar cases and different outcomes from outcomes in cases that are different in some material respect. ${ }^{17}$ In other words, judges, even in a system of discretionary apportionment, cannot 'indulge fancy or mere whim'. ${ }^{18}$

A second reason why the contrast between discretionary apportionment and fixed apportionment is less extreme than it might at first glance appear is that, even under a highly fixed apportionment regime, judges still enjoy some discretion. They will, at the very least, have discretion to decide whether the instant case is one to which a fixed apportionment rule applies. For example, if, as in South Australia, legislation provides that damages must be reduced by exactly $25 \%$ if the claimant was injured while 'rel[ying] on the care and skill of a person who was intoxicated', ${ }^{19}$ the judge will have some leeway to decide what this phrase means (unless he is constrained by a prior interpretation of those words by a decision that is binding on him). The judge will also have discretion to decide whether the words, given the meaning that they are held to bear, encompass the facts of the case.

As has just been explained, even highly discretionary systems limit judicial discretion in certain ways, and even highly fixed regimes do not eradicate discretion. But there is a third reason why the distinction between discretionary apportionment and fixed apportionment is not black and white. It is possible to develop rules that combine in significant measures aspects of the paradigm of discretionary apportionment and features of the paradigm of fixed apportionment. A legislature, for example, might specify that a given act of contributory negligence will attract a discount of at least $25 \%$, but incorporate a safety-valve discretion that allows judges to depart from the rule if they consider that applying it would produce injustice or if the case is exceptional. Such a rule would lie somewhere near the middle of the spectrum between discretionary apportionment and fixed apportionment.

Although the contrast between the paradigms of discretionary apportionment and fixed apportionment is not as sharp as it might first appear to be, the two paradigms of apportionment are obviously distinct, and it is usually possible to say whether any given rule is more inclined to one than to the other.

\section{THE EMBRACE OF DISCRETIONARY APPORTIONMENT}

The British apportionment provision is contained in s 1 of the Law Reform (Contributory Negligence) Act 1945. This provision, which has been widely replicated

16. As HLA Hart observed in his 'lost' essay on discretion (HLA Hart 'Discretion' (2013) 127 Harv L Rev 652 at 657): 'When we are considering the use of discretion in the Law we are considering its use by officials who are holding a responsible public office. It is therefore understood that if what officials are to do is not rigidly determined by specific rules but a choice is left to them, they will choose responsibly having regard to their office and not indulge in fancy or mere whim ...'.

17. Statements regarding this obligation made at the highest level include Matadeen $v$ Pointu [1999] 1 AC 98 (PC) 109; Cinar Corporation v Robinson [2013] SCC 73; [2013] 3 SCR 1168 at 1212 [106].

18. Hart, above n 16 , at 657 .

19. Civil Liability Act 1936 (SA), s 47.(1)(a)(ii). This provision is discussed below in section 4(a)(ii). 
elsewhere ${ }^{20}$ relevantly states that where the claimant is guilty of contributory negligence the 'damages recoverable ... shall be reduced to such extent as the court thinks just and equitable having regard to the claimant's share in the responsibility for the damage'. This provision plainly opts for a system of discretionary apportionment. It does not, for example, specify ex-ante reductions in damages that are to be applied to certain types of case. Furthermore, the words 'just and equitable' give the courts significant leeway to determine the appropriate apportionment. ${ }^{21}$ They permit the judge to take account of nearly all of the circumstances of the case at hand. Consistently with the fact that the provision opts a system of for discretionary apportionment, it has often been stressed that it requires each case to be decided on its own facts ${ }^{22}$ and that appellate intervention will be warranted only where the trial judge's holding is 'plainly', 23 'fundamentally' ${ }^{24}$ or 'clearly' ${ }^{25}$ incorrect.

While the British apportionment provision clearly gives judges great freedom, so that it can properly be said to opt for a system of discretionary apportionment, it fetters the discretion that it affords in at least two ways. First, it states that the discretion must be exercised having regard to 'the claimant's share in the responsibility for the damage'. ${ }^{26}$ This excludes certain facts from consideration. For example, it would be wrong, given this statutory language, for the court to take into account in determining the appropriate discount the fact that the claimant risked the defendant's safety or the safety of third parties. Such facts do not relate to the claimant's responsibility for the damage, which means, of course, the damage suffered by the claimant. ${ }^{27}$ As Glanville Williams put it, 'fault not contributing to the damage cannot be taken into account' ${ }^{28}$ The fact that the discretion must be exercised having regard to 'the claimant's share in the responsibility for the damage' also means that judges have no choice but to consider certain things. For example, the court must take into account the defendant's share in the responsibility for the damage since, as Hale LJ noted in Eagle v Chambers, '[i]t is . . impossible to consider the claimant's "share" without also considering that of the defendant' ${ }^{29}$

20. See eg Law Reform (Miscellaneous Provisions) Act 1965 (NSW), s 9; Contributory Negligence Act 1947 (NZ), s 3.

21. 'It is clear that the Act intends to give a very wide discretion to the judge or jury entrusted with the ... task of making the apportionment. Much latitude must be allowed to the ... tribunal in arriving at a judgment as to what is just and equitable': Pennington $v$ Norris (1956) 96 CLR 10 (HCA) 15-16. See also Stanton v Collinson [2010] EWCA Civ 81; [2010] RTR 26 at [26].

22. 'The significance of the various elements involved in [the determination of the appropriate apportionment] will vary from case to case': Podrebersek $v$ Australian Iron \& Steel Pty Ltd (1885) 59 ALJR 492 (HCA) 494; '[I]t is important to remember that every case depends upon its own facts': Phethean-Hubble v Coles [2012] EWCA Civ 349; [2012] RTR 31 at [80].

23. Phethean-Hubble v Coles [2012] EWCA Civ 349 at [86].

24. Dixon v Clement Jones Solicitors (a firm) [2004] EWCA Civ 1005 at [51].

25. Kerry $v$ Carter [1969] 1 WLR 1372 (CA) 1376.

26. Law Reform (Contributory Negligence) Act 1945, s 1(1).

27. This is clear from the opening words of s 1(1): 'Where any person suffers damage as the result partly of his own fault and partly of the fault of any other person or persons, a claim in respect of that damage ....

28. Williams, above n 4, p 390.

29. [2003] EWCA Civ 1107; [2004] RTR 9 at [14]. 
A second way in which the apportionment legislation limits judicial discretion relates to the fact that it stipulates that reductions in damages for contributory negligence must be 'just and equitable'. As mentioned earlier, ${ }^{30}$ it has been held that by these words Parliament intended judges to have regard to the parties' relative blameworthiness and the causative potency of their careless conduct. The fact that judges must take account of these considerations (and perhaps only these considerations) in determining a discount that would be 'just and equitable' limits their discretion. Of course, these twin factors are extremely general and their meaning has never been explained in any detail, so they do little to curtail the discretion that judges enjoy in apportioning damages.

\section{FIXED APPORTIONMENT RULES}

The British apportionment provision and the apportionment provisions in the other major common-law jurisdictions give the impression that discretionary apportionment reigns supreme. However, the true situation is rather different and significantly more complex. Jurisdictions that prima facie accept discretionary apportionment as a consequence of their apportionment legislation often recognise fixed apportionment rules. Four types of fixed apportionment rule can be identified: (1) fixed reduction rules; (2) minimum reduction rules; (3) maximum reduction rules; and (4) rules that limit the permissible discount to a certain range. These types of rule will be discussed seriatim. But, simply so that it can be appreciated immediately what they involve, some examples will be given here. A rule that provides that damages must be reduced for contributory negligence by, say, exactly $25 \%$ is a fixed apportionment rule. A rule that states that damages must be diminished by at least $25 \%$ would be a minimum reduction rule. A rule that stipulates that the greatest reduction in damages that a court can make for contributory negligence is $25 \%$ would be a maximum reduction rule. Finally, a rule that limits the permissible discount to a certain range would include a rule that requires the courts to confine themselves to discounts falling between a $25 \%$ reduction and a $50 \%$ reduction.

\section{(a) Fixed reduction rules}

\section{(I) THE FROOM RULES}

A leading decision regarding the doctrine of contributory negligence is Froom $v$ Butcher. ${ }^{31}$ This was a run-of-the-mill seat belt case. The claimant passenger suffered more serious injuries in an accident that was caused by the defendant driver's negligence than he would have suffered had he used a seat belt. The trial judge held that the failure to wear a seat belt did not constitute contributory negligence. ${ }^{32}$ Lord Denning MR (with whom Lawton and Scarman LJJ agreed) reversed this holding. In the course of doing so, his Lordship laid down several rules to determine

30. See the sources cited in $n 11$.

31. [1976] QB 286 (CA). A perceptive note on Froom is JR Spencer 'Belt up! - the widening scope of contributory negligence' [1976] Camb L J 44.

32. Froom v Butcher [1974] 1 WLR 1297 (QBD). 


\section{Legal Studies}

how damages should be apportioned where the claimant negligently failed to wear a seat belt. Lord Denning MR wrote: ${ }^{33}$

Sometimes the evidence will show that the failure [to wear a seat belt] made no difference. The damage would have been the same, even if a seat belt had been worn. In such case the damages should not be reduced at all. At other times the evidence will show that the failure made all the difference. The damage would have been prevented altogether if a seat belt had been worn. In such cases I would suggest that the damages should be reduced by 25 per cent. But often enough the evidence will only show that the failure made a considerable difference. Some injuries to the head, for instance, would have been a good deal less severe if a seat belt had been worn, but there would still have been some injury to the head. In such case I would suggest that the damages attributable to the failure to wear a seat belt should be reduced by 15 per cent.

A little-noticed fact about Froom is that Lord Denning MR did not adhere strictly to these rules (the 'Froom rules') in disposing of the appeal. Since the evidence was that some of the claimant's injuries would have been completely avoided had the claimant used a seat belt while other injuries would have been incurred regardless of whether the claimant had worn a seat belt, ${ }^{34}$ Lord Denning MR reduced the damages by $20 \% .{ }^{35}$ Technically, in doing so, he deviated from the rules that he established, although the deviation was minor since he settled on a figure that fell midway between the two discounts specified in his rules. It is worth noting that $20 \%$ was the figure by which the trial judge said he would have reduced damages had he found the claimant guilty of contributory negligence ${ }^{36}$ and that the claimant did not suggest that this discount was inappropriate. ${ }^{37}$

Lord Denning MR did not change the law in remarking that damages should not be apportioned if the claimant's negligent failure to wear a seat belt would not have made any difference to the damage. Causally irrelevant contributory negligence by the claimant has never been sufficient to enliven the doctrine of contributory negligence. ${ }^{38}$ However, the situation is otherwise with respect to Lord Denning MR's suggestion that damages should be reduced by $25 \%$ reduction if the damage suffered would have been completely avoided had the claimant worn a seat belt, and by $15 \%$ if the damage would have been less severe. By these remarks, Lord Denning MR isolated two categories of case and suggested that cases falling into those categories should be subject to fixed discounts. In other words, he created fixed reduction rules.

What is the status of the Froom rules? It is arguable that they are merely obiter dicta given that Lord Denning MR did not apply them. One might also fairly contend that Lord Denning MR meant only for them to be guidelines (he spoke in permissive

33. [1976] QB 286 (CA) 296.

34. The claimant suffered injuries to his head, chest and one of his fingers. The head and chest injuries would have been avoided if the claimant had worn a seat belt. The claimant's finger would have been injured regardless of whether he had used a seat belt: Froom v Butcher [1976] QB 286 (CA) 296.

35. Froom v Butcher [1976] QB 286 (CA) 296.

36. Froom v Butcher [1974] 1 WLR 1297 (QBD) 1300.

37. Froom v Butcher [1976] QB 286 (CA) 296.

38. In Caswell v Powell Duffryn Associate Collieries Ltd [1940] AC 152 (HL) 165, Lord Atkin said '[i]f the plaintiff were negligent but his negligence was not a cause operating to produce the damage there would be no defence. I find it impossible to divorce any theory of contributory negligence from the concept of causation.' 
language ${ }^{39}$ ). However, this is not how they have generally been understood by the courts. Judges seem to adhere strictly to them (although no one has carried out the empirical work that is necessary to confirm whether this is so). They have been applied countless times ${ }^{40}$ and attempts to modify them have repeatedly been rebuffed. ${ }^{41}$ The courts have made it crystal clear that they have no appetite for reconsidering them. ${ }^{42}$ On the contrary, the courts have enthusiastically extended them to related contexts, such as a failure of motorcyclists ${ }^{43}$ and bicyclists ${ }^{44}$ to wear crash helmets. ${ }^{45}$ Of course, despite the foregoing, is difficult to be certain regarding the extent to which the Froom rules are determinative in practice. This is partly because most of the cases to which they will have been relevant will have been decided by courts that are situated lower in the judicial hierarchy than the High Court, and decisions of such courts are rarely reported or otherwise made publically available. It is also because litigants are of course free to reach an agreement on the issue of apportionment. Litigants are obviously not forced to accept the Froom rules. There is some evidence that litigants, oddly, sometimes agree to discounts that differ wildly from those established in Froom even though Froom would clearly apply were the case litigated. ${ }^{46}$

When do the Froom rules apply? They are inapplicable where there is an act of contributory negligence additional to failing to wear a seat belt, such as accepting a lift from an intoxicated driver, ${ }^{47}$ travelling in a car with the knowledge that its brakes were defective ${ }^{48}$ or travelling in the boot of a car. ${ }^{49}$ In such cases, discounts greater than those enunciated in Froom are often applied. It should also be noted that the Froom rules will not necessarily apply even when they are prima facie applicable. Judges have a discretion to depart from them (recall that they were not applied in Froom itself). However, the courts have said firmly and repeatedly that they will be departed from only in 'rare or exceptional" ${ }^{50}$ cases. It has been declared that it "is of the greatest importance that they should be generally be kept to' ${ }^{51}$ and that they are not 'mere

39. See the text accompanying $n 33$.

40. See eg Patience v Andrew [1983] RTR 447 (QBD); Palmer v Kitley [2008] EWHC 2819 (QB); Mabiriizi v HSBC Insurance (UK) Ltd [2011] EWHC 12080 (QB) at [10].

41. See eg the unsuccessful attempts made in Gawler v Raettig [2007] EWHC 373 (QB) at [39]-[46]; Stanton v Collinson [2010] EWCA Civ 81; [2010] RTR 284 at [26].

42. This message is made particularly clear in Stanton v Collinson [2010] EWCA Civ 81 at [27].

43. Capps v Miller [1989] 2 All ER 333; [1989] 1 WLR 839 (CA).

44. Smith $v$ Finch [2009] EWHC 53 (QB).

45. For discussion, see J Fulbrook 'Cycle helmets and contributory negligence' [2004] J Pers Injury L 171. The rules were not extended to riding in the boot of a car: Gleeson v Court [2007] EWHC 2397 (QB); [2008] RTR 10 at [25] (30\%).

46. See eg Madden v Quirk [1989] 1 WLR 702 (QBD) (5\%); Hitchens v Berkshire Council (unreported, Court of Appeal of England and Wales, 21 June 2000) (50\%); Demetriou v Holdsworth (unreported, High Court of England and Wales, 11 May 2001, WL 949928) (10\%). 47. See eg Sloan v Triplett 1985 SLT 294 (OH) (33.3\%); Hill v Chivers 1987 SLT $323(\mathrm{OH})$ $(33.3 \%)$.

48. See eg Gregory v Kelly [1978] RTR 426 (QBD) (40\%).

49. See eg Gleeson v Court [2007] EWHC 2397 (QB); [2008] RTR 10 (30\%).

50. Gawler v Raettig [2007] EWHC 373 (QB) at [26]. See also Jones v Wilkins [2001] RTR 19 (CA) [18].

51. Capps v Miller [1989] 2 All ER 333 (CA) 341; [1989] 1 WLR 839, 849-850 (CroomJohnson LJ). 
suggestion or guidance'. ${ }^{52}$ Only a handful of cases can be found in which they were not applied where facts that would ordinarily trigger them existed. ${ }^{53}$ Where the defendant contends that the discount for contributory negligence should be increased above $25 \%$ it seems that only a 'conscious decision' by the claimant to take a risk will render a case sufficiently exceptional to escape from the grip of the Froom rules. ${ }^{54}$

The Froom rules have not been swallowed hook, line and sinker by the courts in any other jurisdiction. ${ }^{55}$ However, they are not infrequently referred to by courts in Australia $^{56}$ and Canada $^{57}$ and are apparently influential in those countries. Nevertheless, the courts in those jurisdictions are not wedded to them. For example, in Snushall $v$ Fulsang, Juriansz JA wrote, 'Canadian courts generally ... have not expressed approval of the three-level framework Lord Denning suggested. ${ }^{58}$ In Heller v Martens Fruman JA observed, 'It is obvious that in English seat belt cases apportionment is based on a fixed qualification that is considerably less discretionary than a typical Alberta analysis. ${ }^{59}$

\section{(II) OTHER FIXED REDUCTION RULES}

No other fixed reduction rules appear to have been developed by the courts in any of the major common-law jurisdictions. Tugendhat $\mathrm{J}$ recently claimed in Best $v$ Smyth that 'since Owens v Brimmell [1977] QB 859 the figure of $20 \%$ is commonly regarded as an appropriate reduction for a claimant who has got into a vehicle when he must have known that the driver had had too much to drink' ${ }^{60}$ It is doubtful, however, whether any fixed reduction rule to this effect exists, at least in Britain. The judge in

52. Gawler v Raettig [2007] EWHC 373 QB at [25]; contra Jones $v$ Wilkins [2001] RTR 19 (CA) [17] (Lord Denning MR 'was not there seeking to put forward the figure of 25 per cent contribution as an absolute and immutable ceiling in every single case') (Keene LJ (dicta)); Chae v Min [2001] ABQB 1071 at [25] ('[Lord Denning MR] proposed a mere guideline') (Veit J).

53. See eg Roberts $v$ Sparks [1977] CLY 2643 (20\%); Salmon v Newland (1983) The Times 16 May (20\%); Capps v Miller [1989] 2 All ER 333; [1989] 1 WLR 839 (CA) (10\%); Hazlett v Robinson [2014] NIQB 17 (20\%).

54. Gawler v Raettig [2007] EWHC $373(\mathrm{QB})$ at [31] (suggesting that a discount above 25\% might be warranted where the claimant deliberately ignored an instruction given by a police officer to use a seat belt). See also Jones $v$ Wilkins [2001] RTR 19 (CA) [19] (a contribution claim).

55. Including Scotland: see eg Smith v Donald McLaren Ltd 1977 SLT (Notes) $51(\mathrm{OH})$ (20\%); Sloan v Triplett 1985 SLT 294 (OH) 297 (20\%).

56. See eg Hallowell $v$ The Nominal Defendant (Queensland) [1983] 2 Qd R 266 (Full Ct) 268; Ferrett $v$ Worsley (1993) 61 SASR 234 (Full Ct) 242; Richard v Mills [2003] WASCA 97 at [26].

57. 'Froom v Butcher... has been widely accepted and approved in Canada and has acquired a settled place in our jurisprudence': Fowler v Schneider National Carries Ltd [2001] NSCA 55; (2001) 193 NSR (2d) 206 at [52]; 'Many Canadian courts have relied on Lord Denning's 1975 decision in Froom v Butcher': Chae v Min [2001] ABQB 1071 at [24]; 'Lord Denning's judgment in Froom has been cited consistently in Canadian cases': Snushall v Fulsang (2005) 258 DLR (4th) 425 (ONCA) [36].

58. (2005) 258 DLR (4th) 425 (ONCA) [36].

59. [2002] ABCA 122; (2002) 4 Alta LR (4th) 51 at [38].

60. [2010] EWHC $1541(\mathrm{QB})$ at [12]. See also Gleeson v Court [2007] EWHC $2397(\mathrm{QB})$; [2008] RTR 10 at [22]. 
Owens, Watkins $\mathrm{J}$, did nothing to indicate that he was doing anything other than making a decision solely for the purpose of the proceedings before him. (Certainly, he did not offer remarks analogous to those made by Lord Denning MR in Froom.) Some judges have denied that Owens sets the figure of $20 \%$ in stone. ${ }^{61} \mathrm{~A}$ welter of relevant cases can be found in which a different discount was applied. ${ }^{62}$

Statutory fixed reduction rules exist in some jurisdictions. For example, in parts of Australia ${ }^{63}$ and Canada, ${ }^{64}$ legislation provides that damages must be reduced by $25 \%$ for failing to wear a seat belt. ${ }^{65}$ In the case of the Northern Territory, this discount, incredibly, applies even if the failure to wear a seat belt would not have made a difference to the damage and even if the failure to use a seat belt was not unreasonable. In Canada, the statutes stipulate that the discount applies unless the failure to wear a seat belt was not causally related to the claimant's damage. No exception is made where the failure was reasonable. Statutory fixed reduction rules are not confined to the seat belt context. In South Australia, legislation provides for an irrebuttable presumption of contributory negligence where the claimant 'relied on the care and skill of a person who was intoxicated' and, where this presumption applies, the damages must be diminished by $25 \%$. This discount is increased to $50 \%$ if the defendant was intoxicated to a sufficient degree. ${ }^{66}$ None of these statutory fixed reduction rules gives the court the power not to apply the prescribed discount.

\section{(b) Minimum reduction rules}

The second type of fixed apportionment rules are 'minimum reduction rules'. Such rules require damages to be reduced by at least a specified percentage where the claimant is guilty of contributory negligence. Whereas fixed reduction rules result in damages being reduced in all cases that fall within a given category by a set amount (and by no more and no less), minimum reduction rules demand that all cases that fall within a particular category have the award cut back by at least a prescribed figure. Greater reductions in damages are permitted. Minimum reduction rules and fixed reduction rules are clearly fundamentally different from each other. Fixed reduction rules eliminate the discretion of the trial judge, save for the discretion that the judge has as to whether the rule applies in the first place. By contrast, minimum reduction rules merely eliminate certain discounts from consideration (eg discounts of less than

61. Stinton v Stinton [1993] PIQR P135 (QBD) 140; Currie v Clamp's Executor 2002 SLT $196(\mathrm{OH})$ [22].

62. See eg Meah v McCreamer [1985] 1 All ER 367 (QBD) (25\%); Stinton v Stinton [1993] PIQR P135 (QBD) (33.3\%); Donelan v Donelan [1993] PIQR P205 (QBD) (75\%) (however, it was said that 'the fact of this case [were] wholly exceptional' (at 210)); Currie v Clamp's Executor 2002 SLT $196(\mathrm{OH})$ [22] (33.3\%).

63. Motor Accidents (Compensation) Act (NT), s 11(1); Civil Liability Act 1936 (SA), s 49(3).

64. Insurance Act, RSNB 1973, c I-12, s 265.2(1); Automobile Insurance Act, FSNL 1990, c A-22, s 28.1 .

65. The Northern Territory and South Australian legislation extends to a failure to wear a safety helmet. The legislation in South Australia also applies if the claimant travelled in a compartment of a vehicle other than the passenger compartment.

66. Civil Liability Act 1936 (SA), s 47(3) and (6). 
25\%). The judge is left free to reduce the claimant's damages by more than the prescribed minimum. Minimum reduction rules still depart, of course, from the paradigm of discretionary apportionment. This is because the court is forced to apply a discount of at least the size prescribed even if it would, but for the minimum reduction rule, have opted for a smaller discount.

Many Australian legislatures have provided for minimum reduction rules in intoxication cases ${ }^{67}$ These rules provide that damages must be reduced by at least $25 \%$ where the claimant is intoxicated ${ }^{68}$ or where he negligently 'relied' on an intoxicated defendant. ${ }^{69}$ In some jurisdictions, the minimum discount is increased to $50 \%$ where the claimant's contributory negligence is thought to be aggravated, such as where the claimant was a driver, ${ }^{70}$ or where the person on whom the claimant relied was a driver. ${ }^{71}$ Minimum reduction rules also exist in Canada. In two provinces, ${ }^{72}$ legislation provides that where the claimant fails to wear a seat belt and he contributes to the damage in some additional way, his damages shall be reduced by not less than $25 \%$, unless the claimant proves that the failure to wear a seat belt was causally unrelated to his damage. It does not seem that there are any minimum reduction rules in the UK.

\section{(c) Maximum reduction rules}

Maximum reduction rules cap the discount that a court can apply for contributory negligence (eg at 25\%). Maximum reduction rules are the inverse of minimum reduction rules. They depart from the paradigm of discretionary apportionment because they restrict the discount for contributory negligence to below a particular amount even if the court would, but for the limit, have imposed a greater discount. It is arguable that there is a judicially created maximum reduction rule in seat belt cases in at least some Canadian provinces. In Snushall v Fulsang Juriansz JA, speaking for the Ontario Court of Appeal, opined that a discount greater than $25 \%$ in seat belt cases would be 'unreasonable' ${ }^{73}$ In a striking departure from the 'never say never' ethos that is generally embraced by judges, his Honour wrote, ${ }^{74}$ 'In my view, there is no reason to leave open the possibility that a greater apportionment might be appropriate in a rare case. ${ }^{75}$ In Vigoren $v$ Nystuen Richards JA, with whom the other members of the Saskatchewan Court of Appeal agreed, said 'the 25\% figure should apply as a firm

67. One jurisdiction in Australia has a minimum reduction rule that applies in the seat belt context. Section 22(4) of the Motor Accidents (Liabilities and Compensation) Act 1973 (Tas) provides for a minimum reduction of $15 \%$ for failing to wear a seat belt.

68. Civil Liability Act 2002 (NSW), s 50; Civil Liability Act 2003 (Qld), s 47; Civil Liability Act 1936 (SA), s 46.

69. Civil Liability Act 2003 (Qld), s 48(4).

70. Civil Liability Act 2003 (Qld) s 47(5); Civil Liability Act 1936 (SA), s 46(4).

71. Civil Liability Act 2003 (Qld), ss 48-49; Civil Liability Act 1936 (SA), s 47.

72. Insurance Act, RSNB 1973, c I-12, s 265.2(2); Automobile Insurance Act, RSNL 1990, c A-22, s 28.1(2); Automobile Insurance Contract Mandatory Conditions Regulations, NS Reg 181/2003, s 10(1).

73. Snushall v Fulsang (2005) 258 DLR (4th) 425 (ONCA) [44].

74. 'Never say never' is often an appropriate catchphrase for a judge to have in mind': Al Rawi $v$ Security Service [2010] EWCA Civ 482 at [69].

75. Snushall v Fulsang (2005) 258 DLR (4th) 425 (ONCA) [44]. 
cap' ${ }^{76}$ Legislatures in several jurisdictions in the USA have created maximum reduction rules in seat belt cases. For example, in Michigan the maximum discount in such cases is $5 \% .{ }^{77}$

In the UK, despite some earlier doubts, it seems that the courts cannot reduce damages by $100 \%$ on account of the claimant's contributory negligence. ${ }^{78}$ It might be thought that this rule is a maximum reduction rule (although the precise height of the ceiling is unclear - is it, for example, $95 \%$ or $99 \%$ ?). The better view, however, is that the reason why damages cannot be reduced by $100 \%$ is not because there is a cap on the discount but because the doctrine of contributory negligence will not be engaged to begin with where a court would, if the doctrine applied, be inclined to reduce damages by $100 \% .^{79}$ A court that concludes that a $100 \%$ discount is warranted must consider the claimant to be solely responsible for the damage about which the he complains. But if the claimant is solely responsible for his damage, no tort will have been committed, and if no tort is committed the question of contributory negligence will not even arise for consideration. ${ }^{80}$ It follows that the principle that $100 \%$ discounts are impermissible is not in fact a maximum reduction rule, but a rule about when the doctrine of contributory negligence applies.

\section{(d) The range of permissible discounts in damages}

It is possible for a minimum reduction rule and a maximum reduction rule to be combined to yield a fourth type of fixed apportionment rule. When minimum reduction rules and maximum reduction rules are combined with each other, the court is required to select a discount that falls into a particular range. For example, a legislature might enact a provision that states that a given act of contributory negligence can attract discounts between $40 \%$ and $60 \%$ only. ${ }^{81}$ Such a rule would obviously limit the courts' discretion to determine the appropriate discount. Do rules of this type exist in any common-law jurisdiction? Arguably, such a rule is recognised in Canada in seat

76. [2006] SKCA 47 at [102].

77. MCL 257.710e(6). A 5\% cap also applies in Iowa (Iowa Code Ann, § 321.445(4)), Nebraska (Neb Rev Stat, $\S 60-6,273$ ) and Oregon (Or Rev Stat Ann, § 31.760). In Missouri, the cap is $1 \%$ (Mo Ann Stat, $\S 307.178(4)$ ), while in Wisconsin it is $15 \%$ (Wisconsin Stat, $\S 347.48(2 \mathrm{~m})(\mathrm{g}))$. These caps (with the exception of the Wisconsin cap) are so low that they are, paradoxically, minimum reduction rules too. For example, the cap of $1 \%$ in Missouri is so low that it is also a minimum reduction rule, as courts cannot reduce damages by less than $1 \%$ (at least not justifiably, since a reduction of less than this amount means that there is no responsibility on the part of the claimant, with the result that the doctrine of contributory negligence should not be engaged in the first place, and the issue of apportionment should not arise).

78. Buyukardicli v Hammerson UK Properties plc [2002] EWCA Civ 683 at [7].

79. See further J Goudkamp 'Rethinking contributory negligence' in E Chamberlain, J Neyers and S Pitel (eds) Challenging Orthodoxy in Tort Law (Oxford: Hart Publishing, 2013) pp 344-346.

80. ' $[\mathrm{O}]$ ne does not get to the question of contributory negligence until liability is established': Sharpe v Addison [2003] EWCA Civ 1189, [2007] Lloyd's Rep PN 12 at [32].

81. It is arguable that this is not a separate type of fixed apportionment rule on two grounds. First, rules that restrict the court to discounts within a particular range can be broken down into minimum reduction rules and maximum reduction rules. The second reason has to do with the fact that both minimum reduction rules and maximum reduction rules restrict the court to a particular range too. For example, a rule that requires a minimum $25 \%$ discount in damages restricts the court to discounts that fall between that discount and the upper end of the spectrum. 
belt cases. In Galaske v O'Donnell Cory J remarked, 'The courts in this country have consistently deducted from 5 to 25 percent from claims for damages for personal injury on the grounds that the victims were contributorily negligent for not wearing seat belts. ${ }^{, 82}$ It is not clear, however, whether there is any formal rule that restricts the courts' discretion in this regard, or whether Cory $\mathrm{J}$ was merely observing that most discounts in seat belt cases tend to fall within this range.

\section{(e) Summary}

Although the apportionment provisions in all of the major common-law jurisdictions adopt discretionary apportionment, fixed apportionment rules have crept into the law in these jurisdictions as a result of both judicial and statutory invention. Four different types of fixed apportionment rule have been identified: (1) rules that provide for fixed reductions in damages (eg reduction by exactly $25 \%$ ); (2) rules that require the courts to reduce damages by a minimum amount (eg reduction of at least 25\%); (3) rules that cap the maximum discount (eg reduction of not more than 25\%); and (4) provisions that restrict discounts to a particular range (eg reduction between $25 \%$ and $50 \%$ ). Some fixed apportionment rules restrict the judges' discretion to a much greater degree than others. Fixed reduction rules are the most restrictive type of fixed apportionment rule by far. The only discretion that fixed apportionment rules afford judges is the discretion to decide whether they apply in the first place.

\section{THE CONFLICT BETWEEN DISCRETIONARY APPORTIONMENT AND FIXED APPORTIONMENT}

\section{(a) Incompatible paradigms}

Discretionary apportionment leaves the judge essentially free to determine the discount that he thinks is appropriate given the unique circumstances of each case. By contrast, fixed apportionment settles the discount ex ante, at least to some degree. By happenstance, the two approaches to apportionment may result in the same discount in a given case. However, they can produce different outcomes and are, to this extent, in conflict with each other. Consider the following scenario. A claimant passenger is injured in a car accident due to the negligence of the driver of the vehicle. The claimant was not wearing a seat belt. Had the claimant used a seat belt, he would have escaped injury. In England and Wales, the claimant's damages will, pursuant to Froom, be reduced by $25 \%$, unless the case is considered to be exceptional. ${ }^{83}$ Now consider the same scenario with the following modifications made to it. Suppose that the driver of the vehicle was intoxicated (in circumstances where the claimant did not know of, and could not reasonably have discovered, this fact). Suppose also that the driver is an adult whereas the claimant is an adolescent. In the modified scenario, most people would think that the driver carries a significantly greater proportion of responsibility for the claimant's damage than in the original scenario. Yet, by virtue of Froom, damages will still be reduced by $25 \%$ unless, again, the case is considered to be exceptional. Recall that English courts are extremely reluctant to conclude that

82. [1994] 1 SCR 670 (SCC) 682.

83. See the text above accompanying nn 50-53. 
a case is exceptional. ${ }^{84}$ Conversely, were the issue of apportionment determined by a discretionary apportionment rule, the damages would most likely be discounted by a greater percentage in the original scenario than in the modified scenario. Where fixed apportionment rules lead to a different outcome from the system of discretionary apportionment provided for by the apportionment legislation, how should this conflict be resolved? No court has to date, in any jurisdiction, engaged with this question in any reported or electronically available case. Because, however, it could easily arise for consideration, it is worth addressing. For reasons that will be given in a moment, the resolution of conflicts between discretionary apportionment rules and fixed apportionment rules depends on whether a given fixed apportionment rule is statute based or was developed by the courts.

\section{(b) Statutory fixed apportionment rules}

Where a statute provides for a fixed apportionment rule, it is clear that it must prevail over the discretionary apportionment rule laid down by the apportionment legislation. This is because it will invariably be more specific than the rule in the apportionment legislation: generalia specialibus non derogant. Fixed apportionment rules are confined to particular acts of contributory negligence, such as being intoxicated. Conversely, the apportionment provisions are, of course, extremely general. They apply to all conceivable types of negligent and contributorily negligent behaviour. Unsurprisingly, when judges have considered statutory fixed reduction rules, they simply apply them without even mentioning the fact that they collide with the apportionment legislation. ${ }^{85}$

\section{(c) Common-law fixed apportionment rules}

The Froom rules are the only well-established judge-made fixed apportionment rules. Because they fetter the discretion that the apportionment legislation gives to judges (according to the way in which they have generally been interpreted by subsequent cases), it can plausibly be argued that Froom (and many decisions that apply the Froom rules) was decided per incuriam. ${ }^{86}$ This is admittedly a bold claim. Froom is one of the best-known cases in the English law of torts and it seems to be regularly applied. It is also true that the test that would be applied to determine whether Froom

84. See the text accompanying nn 50-53.

85. See eg Robbins $v$ Skouboudis [2013] QSC 101 at [52]; Hawira v Connolly [2008] QSC 4 at [53].

86. John Spencer seemed to hint at this in a note in Froom. Referring to 'the way in which the Court of Appeal tried to prescribed in advance the percentage by which a plaintiff's damage should be reduced', Spencer wrote, 'As the apportionment of damages for contributory negligence is usually treated as a matter for the discretion of the court in question, it is possible to raise academic objections to this': Spencer, above n 31, at 45. Robert Stevens is explicit. He contends that the fixed reduction rules laid down in Froom 'flagrantly ignor[e] the statutory language': R Stevens 'Should contributory fault be analogue or digital?' in A Dyson, J Goudkamp and F Wilmot-Smith (eds) Defences in Tort (Oxford: Hart Publishing, 2015) ch 13. Cf Stanton v Collinson [2010] EWCA Civ 81; [2010] RTR 26 at [26] where Hughes LJ said that the fact that the apportionment legislation gives great discretion to judges 'permits an approach such as adopted in Froom v Butcher'. 
was decided per incuriam is difficult to satisfy. ${ }^{87}$ However, it could not fairly be said that the claim is far-fetched. Two distinguished scholars claim (or arguably claim) that Froom was decided in disregard of the apportionment legislation. ${ }^{88}$ It should also be noted that the proposition that is relevantly being advanced in this paper is merely that it can seriously be argued that Froom was decided per incuriam. The case is put no higher than that. Froom has, as noted above, been challenged on several occasions, ${ }^{89}$ but not on this ground and, given the efforts that have been made to displace Froom, it is well worth drawing attention to this potential chink in its armour.

It might be replied that Froom is compatible with the apportionment legislation on the ground that Lord Denning MR in that case was merely endeavouring to interpret the words 'just and equitable' in the apportionment legislation. So understood, Lord Denning MR did not exceed his judicial function but, rather, simply sought to discern what Parliament meant by the words 'just and equitable'. To put this counterpoint in the factual context in Froom, the Froom rules do nothing more than explain what a 'just and equitable' reduction in damages is in seat belt cases; that is, either $15 \%$ or $25 \%$, depending on how great a difference wearing a seat belt would have made. It is doubtful, however, whether what Lord Denning MR did in Froom was an exercise in statutory interpretation. Compare, in this regard, the cases that establish that it is relevant to consider the relative blameworthiness of the parties and the causal potency of their acts in determining what a 'just and equitable' allocation of responsibility is. ${ }^{90}$ It can persuasively be argued that the identification of these twin factors as relevant to the determination of the amount by which damages ought to be reduced for contributory negligence is simply an attempt to interpret the words 'just and equitable'. The laying down of the Froom rules is a fundamentally different exercise from the identification of these twin factors. It is quite clear that the discounts embraced by Lord Denning MR are neither more justifiable nor less justifiable than any other discounts, and there is no reason to think that these discounts represent those that the legislature had in mind (there is, indeed, no evidence that the legislature had any particular discount in mind). The point was made nicely by Richards JA in Vigoren $v$ Nystuen. Richard's JA said 'There is no precise and self-evidently correct amount by which the plaintiff's claim should be reduced. Lord Denning [in Froom v Butcher] could, no doubt, have chosen a somewhat higher or lower number for his benchmark figure[s]. No one would pretend that [the figures were] the only rational choice[s] available. ${ }^{91}$ Consider also what Lord Denning MR said in Froom in an attempt to justify his decision to lay down the fixed reduction rules. His Lordship wrote, 'Suffice it to assess a share of responsibility which will be just and equitable in the great majority of cases. ${ }^{92}$ These words are revealing since they recognise that there will be some cases in which the reduction in damages yielded by the Froom rules will not be just and equitable. In this passage, Lord Denning MR essentially acknowledged that the rules that he established were incompatible with the legislation. Even if, contrary to what has been argued, Lord Denning MR was merely seeking to interpret the words in the statute, this is not, on the whole, how his reasons have been understood by subsequent cases, as has been

87. It is set out in Morelle Ltd v Wakeling [1995] 2 QB 379 (CA) 408.

88. See $n 86$.

89. See $n 41$.

90. See the text accompanying $n 11$.

91. [2006] SKCA 47 at [98]. See also Gleeson v Court [2007] EWHC 2397 (QB); [2008] RTR 10 at [24].

92. [1976] QB 286 (CA) 296 (emphasis added). 
explained above..$^{93}$ For the foregoing reasons, it is certainly arguable that Froom (and the relevant cases decided in its wake) was decided per incuriam.

\section{ADVANTAGES AND DISADVANTAGES}

Nothing that has been said so far addresses directly the respective merits and demerits of discretionary apportionment and fixed apportionment. It is to this issue that attention will now be turned. The discussion that follows here relies, to a degree, on theorising regarding discretion in other parts of the law, especially the law of evidence, where the tendency, at least in some jurisdictions, including the UK, has been to leave an increasing number of issues to be resolved by judicial discretion, ${ }^{94}$ and sentencing in the criminal law, where the opposite drift can be detected. ${ }^{95}$ To an extent, the pros and cons of discretionary apportionment rules and fixed apportionment rules are the same as those that arise in connection with the use of judicial discretion in the law of evidence and sentencing. However, the analogy is imperfect and hence should not be taken too far. For example, in (criminal) evidence and sentencing special concern is properly shown for defendants or offenders, for obvious reasons, whereas tort law, as is well known, takes a more even-handed approach to the parties' interests.

\section{(a) The case for discretionary apportionment}

A case in favour of discretionary apportionment was made in an important Australian report - the Ipp Report ${ }^{96}$ - that advised the governments of Australia how the tort system should be made more affordable to address a perceived 'insurance crisis'. The authors of this report said: ${ }^{97}$

[C]ontributory negligence come[s] in an infinite variety of forms. From one case to another, the respective culpability of the plaintiff and defendant, and their relative causal contributions to the death or injury may differ widely. It is impossible to fix a minimum, just and equitable apportionment of responsibility to the plaintiff applicable to cases where the plaintiff's contributory negligence involves a certain type of behaviour. In the opinion of the Panel, any such reduction would be arbitrary and unprincipled, and could work injustice in some cases. The Panel considers that any fettering of judicial discretion to apportion damages for contributory negligence is undesirable.

The essential claim made here is that discretionary apportionment rules are superior to fixed apportionment rules because the latter rules are arbitrary while the former permit a more nuanced response to the individual circumstances of each case. This argument clearly has some force. If a fixed apportionment rule is laid down, there is a danger that dissimilar cases will be treated in the same way, and that similar cases will be

93. See section 4(a)(i) above.

94. I have found particularly insightful the treatment in C Tapper 'The law of evidence and the rule of law' (2009) 68 Camb L J 67.

95. See the penetrating analysis in A Ashworth Sentencing and Criminal Justice (Cambridge: Cambridge University Press, 4th edn, 2005) pp 30-31, 41-42, 51-54, 72-74.

96. Commonwealth of Australia Review of the Law of Negligence: Final Report (Canberra: Canprint Communications, 2002).

97. Ibid, p 126 [8.16]. 
handled differently. For example, if a statute provides that damages must be reduced by exactly $25 \%$ whenever the claimant is guilty of contributory negligence on account of his intoxication, the same discount will be applied to both slightly and grossly intoxicated claimants, to both adolescent and adult claimants, and so on. Similarly, if a statute stipulates that such a discount must be applied whenever a claimant motorist is guilty of contributory negligence in driving in excess of the speed limit, the same discount will be applied irrespective of whether a given claimant was driving $5 \mathrm{mph}$ or $50 \mathrm{mph}$ above that limit and regardless of the prevailing driving conditions. Intuition suggests that the variations in these two scenarios are morally important and that the law would be unjust were it insensitive to them.

This argument in favour of discretionary apportionment should not be overstated. In particular, it would be a mistake to think that discretionary apportionment regimes bring a degree of precision to the apportionment process that is significantly greater than that which exists in fixed apportionment regimes. The truth of the matter is that discounts in a discretionary system are not determined in a scientific or mathematical way. This has often been pointed out. For example, Dean Prosser wrote, 'Obviously any estimate that 40 per cent of the total fault rests with the pedestrian who walks out into the street in the path of an automobile, and 60 per cent with the driver who is not looking and runs him down, represents nothing resembling accuracy based on demonstrable fact. ${ }^{98}$ A more extreme view has been promoted by Richard Epstein. He argues, 'there is nothing about the particular pattern of factual information, even if perfectly known, that demands any unique set of percentages in any given case. All allocation of responsibility between the two parties is arbitrary ... ${ }^{99}$ If Epstein is right, the suggestion that discretionary apportionment is preferable to fixed apportionment because it is more principled is groundless, since on both approaches to apportionment the discount is arbitrarily determined. However, Epstein probably goes too far. It is one thing to say that determining shares of responsibility is not a scientific or mathematical exercise (Prosser's view), and a different thing to say that it is an arbitrary exercise (Epstein's position). While it is impossible, for example, justifiably to say that a defendant in a given case is exactly $50 \%$ more responsible for certain damage than the claimant, it is not impossible to say, non-arbitrarily, that a given defendant is more responsible for particular damage than the claimant.

\section{(b) The case for fixed apportionment}

What is the case in favour of fixed apportionment? One thing that fixed apportionment rules have going in their favour is that they make the outcome of litigation more certain, especially if they are rarely departed from, as is the case, for example, with the Froom rules. ${ }^{100}$ Thus, in England and Wales a claimant who is guilty of contributory negligence on account of failing to wear a seat belt can usually discover with great certainty the percentage by which his damages will be discounted on account of

98. WL Prosser 'Comparative negligence' (1953) 41 Cal L Rev 1 at 9. See also Williams, above $\mathrm{n} 4, \mathrm{p} 158$ ('It must be admitted that in attempting to assess degrees of negligence the judge is trying to measure the immeasurable').

99. RA Epstein 'Plaintiff's conduct in products liability actions: comparative negligence, automatic division and multiple parties' (1979) 45 J Air L \& Comm 87 at 109-110.

100. See section 4(a)(i) above. 
contributory negligence. All other things being equal, the more predictable the outcome of litigation, the more likely it is that litigants will settle their dispute. ${ }^{101}$

A second advantage of fixed apportionment rules is that they reduce the cost of litigation. A rule that, for example, stipulates that damages must be reduced by $25 \%$ on account of a given act of contributory negligence leaves much less room for evidence to be called and for submissions to be made in relation to the issue of apportionment than a rule that states, as the apportionment legislation does, that damages should be reduced to such extent as is 'just and equitable' where the claimant is guilty of contributory negligence. Under the imagined former rule, the only evidence that would relevantly be admissible is that which casts light on whether the claimant committed the act of contributory negligence that triggers the rule. Conversely, under the latter rule, a vastly wider range of evidence would be prima facie admissible. Indeed, any evidence that concerns the relative blameworthiness of the parties and the causal potency of their acts - these being the twin factors that the courts have identified as bearing on the determination of a 'just and equitable' discount ${ }^{102}-$ would be relevant. Lord Denning MR was mindful of this factor in Froom. His Lordship wrote, 'Th[e] question [of apportionment] should not be prolonged by an expensive inquiry into the degree of blameworthiness on either side, which would be hotly disputed.' ${ }^{103}$

Thirdly, fixed apportionment rules can promote consistency in the way in which cases are decided. There is a great danger under a system of discretionary apportionment that similar cases will be treated differently and that different cases will be handled in a like manner. ${ }^{104}$ The danger of disparate outcomes is particularly acute given that the vast majority of cases in which apportionment is in issue are decided in county courts ${ }^{105}$ (and in institutionally equivalent courts in other jurisdictions). This is

101. ' $[T]$ here is a powerful public interest in there being no [prolonged or intensive enquiry into] fine degrees of contributory negligence, so that the vast majority of cases can be settled according to a well-understood formula and those few which entail trial do not mushroom out of control': Stanton v Collinson [2010] EWCA Civ 81; [2010] RTR 284 at [26]; 'There is value in having clear guidelines normally applicable, so as to aid parties in arriving at sensible settlements': Jones $v$ Wilkins [2001] RTR 19 (CA) [18].

102. See the text accompanying $\mathrm{n} 11$.

103. Froom v Butcher [1976] QB 286 (CA) 296. It may well have been important that Froom was a low-value case. The trial judge assessed damages at $£ 450$, which equates to approximately $£ 4,000$ today. The cost of trying the issue of apportionment will be disproportionate to what is at stake in many cases.

104. Consistency was clearly a central concern of Lord Denning MR in Froom v Butcher [1976] QB 286 (CA). He was particularly vexed by the divergent views that the courts had taken on the issue of whether a claimant who failed to wear a seat belt was guilty of contributory negligence (at 290-291, 294). His Lordship was eager to lay down a firm rule in this regard; namely, that a failure to wear a seat belt would constitute contributory negligence, save in exceptional cases. However, it is plain that Lord Denning MR was also concerned about the disparate reductions that had been imposed in seat belt cases in those matters in which the judge had found that the claimant was guilty of contributory negligence in failing to wear a seat belt. His Lordship canvassed the wide range of discounts that judges had adopted in apparently similar cases (at 290).

105. Most cases in which apportionment for contributory negligence is in issue are plainly personal injury cases. The vast majority of such cases are brought in the county courts: P Cane Atiyah's Accidents, Compensation and the Law (Cambridge: Cambridge University Press, 8th edn, 2013) pp 201-202. 
because the decisions of the county courts are not publically available and so opportunities for judges to refer to each other's decisions on apportionment with a view to achieving a degree of consistency are extremely limited. The difficulty with this situation is compounded by an apparent lack of appellate oversight of decisions on apportionment. It is a well-established principle that appellate courts will rarely review decisions regarding apportionment. They will intervene only exceptionally and where it is clear that the first-instance decision is flawed. ${ }^{106}$ The lack of appellate control means that in a system that is committed to the paradigm of discretionary apportionment, it is virtually certain that there will be significant diversity in the way in which the issue of apportionment is decided at first instance, in violation of the principle that like cases should be decided the same way and that dissimilar cases should be treated differently. Even if such diversity does not presently exist, the risk that it will develop is substantial and is hence a cause for concern.

Fourthly, fixed apportionment rules promote the rule of law. In an ideal world, every possible situation would be catered for by a rule that is settled ex ante. The development of comprehensive set of rules by which we are to be governed is one of the demands made by the rule of law. ${ }^{107}$ Of course, because we lack perfect knowledge of the world, and because our language is not perfectly precise, it is impossible to comply absolutely with this goal. The use of discretion by judges to deal with disputes the resolution of which cannot be provided for in advance is, therefore, inevitable. But it is very doubtful that the current state of affairs in relation to apportionment for contributory negligence is as close to the ideal as can be achieved. Although many fixed apportionment rules exist throughout the common-law world, relatively few fixed apportionment rules exist within a single jurisdiction. In England and Wales, for example, the only fixed apportionment rules are those established by Froom, and none exist elsewhere in the UK. Most jurisdictions are under the spell of the apportionment provision which, as has been explained, imposes an apportionment regime that is about as close to a purely discretionary system as is possible to achieve.

\section{REFORM RECOMMENDATIONS}

The previous section set out the case for both discretionary apportionment and fixed apportionment. There are certainly advantages to discretionary apportionment but, as the foregoing discussion hopefully made clear, the same is true of fixed apportionment. It is very likely that a balance - a happy medium - between these two approaches to apportionment needs to be achieved. A highly discretionary system would be too unpredictable and a highly fixed system would be insufficiently sensitive to the individual circumstances of each case. If this is right, a problem exists given that many jurisdictions are in the thrall of the paradigm of discretionary apportionment. This imbalance should be redressed. Reducing judicial discretion would promote certainty in the law, reduce the cost of litigation, tend to ensure consistency in outcomes (in circumstances where inconsistency is either already rife or there is a great risk that it will become rife) and bring this area of law into increased compliance with the rule of law. How, precisely, should the law be shifted in the direction of fixed apportionment?

106. See section 3 above.

107. See the classic discussion in LL Fuller The Morality of Law (New Haven, CT: Yale University Press, rev edn, 1969) ch 1. 


\section{(a) A structured discretion}

One option is to amend the apportionment legislation so that the discretion that it confers upon judges is more structured. The legislation in all of the major commonlaw jurisdictions currently permits judges to consider or to exclude from consideration almost any facts or factors that they wish. ${ }^{108}$ The legislation could be changed so that it requires judges specifically to consider certain facts or factors. Such facts or factors might include, for instance, the respective ages of the parties, the ease with which the parties could have avoided or reduced the risk of damage that materialised, the gravity and magnitude of the risk that the parties' respective conduct created or increased, whether the parties were subjectively aware of the risk in question and whether a given discount would tend to promote certain goals, such as deterrence or punishment (in the event that those goals are deemed to be relevant). These facts and factors are merely meant, it is stressed, to illustrate considerations that might be incorporated within the apportionment legislation to lend some structure to the discretion which it confers upon judges. Of course, amending the apportionment legislation to make the discretion that it affords judges more structured would be a very modest reform. It would merely nudge the law in the direction of fixed apportionment. Were it adopted, judges would retain very significant freedom to determine the amount by which damages should be reduced for contributory negligence, and provided that they touched upon facts or factors that were relevant to the case at hand, their decisions would be effectively insulated from appellate interference. Therefore, while implementing this proposed change might improve the present situation, the improvement would be slight. The system would remain an essentially discretionary one.

\section{(b) Increase public availability of decisions on apportionment}

Another relatively modest reform would be to make more decisions on apportionment publically available and thereby increase their transparency. As explained above, ${ }^{109}$ the way in which most judges apportion damages is currently extremely opaque, because there is no convenient way to access decisions of courts that are positioned lower in the judicial hierarchy than the High Court in the case of England and Wales (or of courts in other jurisdictions that are similarly situated in the judicial hierarchy). There is every reason to think that the vast majority of apportionment cases are decided by such courts. Were more determinations regarding apportionment publically available, judges would be able to refer to other cases more readily and they would be obliged, given the nature of the judicial function, ${ }^{110}$ to try to achieve at least a fairly high degree of consistency. In turn, this would tend to make the likely discount in any given case more certain. While increasing the visibility of decisions has would have these advantages, this reform would also be an extremely small step towards the paradigm of fixed apportionment. Judges would obviously remain largely free to apply the discount that they felt was most appropriate to any given case. It should also be recognised that increasing the accessibility of relevant decisions will not necessarily mean that judges will consult more cases. Busy judges would probably lack the time to make extensive recourse to apportionment decisions, and they might not receive

108. See section 3 above.

109. See above section 6(b).

110. See section 2 above. 
adequate assistance from counsel in this regard, especially in lower courts, where costs are increasingly being extensively regulated in many jurisdictions.

\section{(c) Guidelines on apportionment}

In certain contexts, guidelines exist of which the courts take cognisance when exercising discretion. An excellent illustration of such guidelines is the Guidelines for the Assessment of General Damages in Personal Injury Cases, published by the Judicial College. ${ }^{111}$ This publication suggests brackets of awards of general damages for specific injuries. Its purpose is to assist judges by setting out what the authors consider to be the current levels of awards that have been and are being made by judges up and down the country'. ${ }^{112}$ The courts have described the Guidelines as 'valuable' ${ }^{113}$ and a 'welcome development'. ${ }^{114}$ The guidelines are not, strictly speaking, binding. ${ }^{115}$ They are " "soft law" rather than "hard law"' but "judges will tend to follow them'. ${ }^{116}$ It would be entirely possible for a suitable body to collate in a similar publication discounts for contributory negligence. Releasing such a publication would be very similar to increasing the public availability of decisions, although it might be more effective, since, if it was executed properly, the transaction costs involved in gleaning the relevant information would be significantly lower since the information could be found in a single place. However, it too would entail only a relatively minor shift in the direction of fixed apportionment. Judges would retain significant discretion. This is because guidelines along the lines of the Guidelines for the Assessment of General Damages in Personal Injury Cases would merely be suggestive.

\section{(d) Fixed reduction rules}

Three ways of moving this area of the law towards a fixed apportionment regime lending structure to the discretion afforded to judges pursuant to the apportionment provision, increasing the public availability of decisions and publishing guidelines on apportionment - have been discussed. They are all fairly modest reform options. None of them would limit judicial discretion to nearly the same extent as the fixed apportionment rules canvassed in section 4 of this paper. If, as has been suggested, many jurisdictions have gone much too far in embracing an extreme system of discretionary apportionment, these three options probably do not go far enough to redress the imbalance. A more far-reaching reform may be warranted if the law is to steer a middle course between the Scylla of an extreme system of discretionary apportionment and

111. Judicial College Guidelines for the Assessment of General Damages in Personal Injury Cases (Oxford: Oxford University Press, 11th edn, 2012).

112. Ball v Secretary of State for Energy and Climate Change [2012] EWHC 145 (QB) at [16].

113. Simmons v Castle [2012] EWCA Civ 1039; [2013] 1 WLR 1239, 1241 [10].

114. Heil v Rankin [2001] QB 272, 294 [25].

115. Choudhary v Martins [2007] EWCA Civ 1379; [2008] 1 WLR 617, 621 [10].

116. Wall v Hutuelle de Poitiers Assurances [2014] EWCA Civ 138 at [24]. Cf the sentencing guidelines that are published by the Sentencing Council pursuant to $\mathrm{Pt} 4 \mathrm{Ch} 1$ of the Coroners and Justice Act 2009. These guidelines specify the range of sentences that are thought to be appropriate for particular categories of offence (s 121(4)), and they 'must' be followed by the courts unless the court is satisfied that doing so would be contrary to the interests of justice (s 125). 
the Charybdis that represents a highly fixed apportionment regime. What about fixed apportionment rules? Should more fixed apportionment rules be introduced? Welcoming them into the law would certainly do more than the three other potential reforms that have just been mentioned to strike a balance between the paradigms of discretionary apportionment and fixed apportionment. As discussed above, there are several different types of fixed apportionment rule. ${ }^{117}$ The type of fixed apportionment rule that minimises the input from the judiciary to the greatest extent is the fixed reduction rule, ${ }^{118}$ the Froom rules being an example. While the Froom rules themselves leave judges with discretion as to whether to apply the Froom rules, ${ }^{119}$ once a judge has decided that the Froom rules apply, he has no discretion as to the discount to apply. A precise discount must be applied. Because fixed reduction rules reduce judicial discretion by a much greater amount than the other types of fixed apportionment rule, it is, given the extent of the imbalance in favour of discretionary apportionment, worth concentrating on these rules. How might they sensibly be introduced into the law?

\section{(e) Constraints on fixed reduction rules}

There are limits to the circumstances in which introducing fixed reduction rules would be justified. In order for a fixed reduction rule to be justified, at least four conditions would need to be satisfied. These conditions are as follows: (1) the rule must apply to a group of cases in which there is little relevant factual diversity; (2) cases that fall within the specified group would need to occur reasonably frequently; (3) it must be possible to define a given category of case reasonably clearly; and (4) as with the Froom rules, judges should be permitted to depart from the fixed reduction rule in exceptional circumstances. A few words need to be said about each of these conditions. Condition (1) refers to the need to isolate sets of cases that are relatively homogenous in terms of the facts that are thought to be relevant to the issue of apportionment. Lord Denning MR isolated such a set of cases - seat belt cases - in Froom. According to Lord Denning MR's definition of that category, cases that fall within it present no issues relevant to the apportionment of damages except for whether the failure to wear a seat belt made a difference in terms of the damage suffered. It would plainly not make sense for one who is seeking to establish more fixed reduction rules to define a set of cases that drags within its net cases that vary wildly in terms of their salient characteristics. For example, an inappropriate category of case to which to apply a fixed reduction rule would be a category in which the claimant was guilty of contributory negligence in failing to follow the defendant's instructions. There would be little homogeneity to such a category, and the principle that like cases should be treated similarly and that dissimilar cases should be handled differently would be violated. Cases that fall within it might be thought to require very different treatment depending on, for example, how persistently or brazenly the claimant had failed to follow instructions, the clarity of the instructions and the force with which the need to comply to them was impressed upon the claimant, whether the defendant was a professional who was advising the claimant and the vulnerability of the claimant. What is meant by condition (2), and its importance, is self-evident. There is no utility in developing a fixed reduction rule for a group of cases if cases fall within

117. See section 4 above.

118. See section 4(a) above.

119. See section 4(a)(i) above. 
that group only once in a blue moon. Doing so would add to the complexity of the law with no corresponding gain. Fixed reduction rules should be developed for frequently occurring situations. The significance of condition (3) is also axiomatic. If a given category is not defined with sufficient precision, frequent arguments will inevitably break out as to whether a given case falls within it. This will undermine the goal of promoting certainty, which is one of the reasons for introducing fixed apportionment rules generally. ${ }^{120}$ Condition (4) recognises the limitations of human foresight. No matter how carefully a given category of case to which a fixed reduction rule is to be applied is defined, there are bound to be cases that are sufficiently different from most of the other cases that fall within the category such that they warrant separate treatment. Hence, it would be desirable for judges to enjoy an exclusionary discretion, as they do in the case of the Froom rules, ${ }^{121}$ so that atypical cases can be insulated from the fixed reduction rule. Such a discretion should be exercised sparingly, or else the purpose of creating the fixed reduction rule would be defeated.

Bearing in mind these constraints on the circumstances in which it would be justifiable to introduce fixed reduction rules, which categories of case should be isolated and subjected to fixed reduction rules? To an extent, it is possible to leave this matter to one side for present purposes on the ground that it is subsidiary one. It should first be decided whether more fixed reduction rules should be introduced before categories of case to which such rules should apply are identified. However, simply by way of suggestion, some categories of case to which fixed reduction rules might sensibly be applied include cases in which the claimant drove while intoxicated or travelled with an driver whom he knew or ought to have known was intoxicated, crossed a road without using a conveniently available pedestrian crossing area, crossed a road without checking for oncoming traffic and failed to wear protective clothing. These are, it is emphasised, merely possible categories of case that are viable candidates for being governed by fixed reduction rules, bearing in mind the conditions that have been mentioned above. It is fairly clear that cases falling within them arise reasonably regularly. ${ }^{122}$ There is arguably little relevant factual diversity in the cases that tend to fall within each category. And it appears that the categories could be defined without intolerable vagueness.

\section{(f) What discount should be applied?}

What discounts should be yielded by any fixed reduction rules that are introduced? This is an easier question to answer than might initially appear to be given that it calls for a value judgement. Subject to what follows, any discount that is selected is neither more nor less justifiable than any other discount. Nevertheless, there are a few principles that should guide the decision-making process in this regard. First, it would not make sense to settle upon very small discounts, such as $1 \%$, or very large discounts, such as $99 \%$. A rule that prescribed such discounts would, as Glanville

120. See section $6(\mathrm{~b})$ above.

121. See section 4(a)(i) above.

122. C Walton et al (eds) Charlesworth and Percy on Negligence (London: Sweet \& Maxwell, 13th edn, 2014) ch 4 contains an extensive and valuable list of apportionment cases. See the numerous intoxication cases involving passengers mentioned in [4-50]. Cases concerning pedestrians are detailed in [4-50] and [4-54]. There is a litany of employment cases contained in [4-69]-[4-73], several of which involve a failure to wear protective clothing. 
Williams pointed out, be a 'needless technicality'. ${ }^{123}$ The claim might as well be allowed to succeed in full or be denied altogether. Secondly, there should be some proportionality between the various discounts laid down by fixed reduction rules. It would not be just, for example, to reduce damages by just $10 \%$ for driving while intoxicated and to reduce damages by $90 \%$ for accepting a lift from an intoxicated driver. Thirdly, minute differences between different discounts should not be tolerated. It would be artificial to select, for instance, a discount of $40 \%$ for one act of contributory negligence and $41 \%$ for another act. Such differences suggest that the selection of the discount is a mathematical exercise, which it is not. ${ }^{124}$

\section{(g) Should fixed reduction rules be introduced by the courts or the legislature?}

Finally, should more fixed reduction rules be introduced by legislation or by the courts? For the reasons given earlier, ${ }^{125}$ the apportionment legislation in all of the major common-law jurisdictions is committed to an extreme discretionary system of apportionment. Rules that limit the discretion that is conferred by the legislation are therefore inconsistent with $i^{126}$ and judges are not free, therefore, to lay down fixed apportionment rules. It is for this reason that it can plausibly be argued that Froom was decided per incuriam. ${ }^{127}$ Somewhat surprisingly, Froom does not seem to have been challenged on this ground. ${ }^{128}$ However, it is obviously inappropriate for the courts to disregard legislation. Any fixed reduction rules that are introduced should be introduced by statute, and the Froom rules should be put on a statutory footing.

It might be objected that statutory fixed reduction rules would undermine the independence of the judiciary. This type of objection is frequently raised in relation to proposals to limit, or laws that in fact limit, judges' discretion in sentencing. ${ }^{129}$ However, this complaint is difficult to justify, in both the sentencing context (except perhaps in fairly extreme cases) and the present setting. ${ }^{130}$ Parliament frequently lays down rules that leave relatively little scope for judicial discretion, in tort law and beyond. It is doubtful that such rules offend the independence of the judiciary. Glossing over the details, which cannot be considered properly here, the principle of judicial independence demands only that Parliament should not exert inappropriate control over the judiciary, such as by removing judges whose decisions are politically unpopular from office or reducing their remuneration. Fixed reduction rules do not seem to raise that spectre. They appear to be fairly far removed from the types of legislative intervention that are regarded as trespassing upon the judicial function.

123. Williams, above $n 4, p 393$. Technically, Williams is only half right given that in very high-value cases every percentage point is potentially highly significant. However, high-value cases are rare relative to the number of low-value cases, where minute adjustments to the size of the discount for contributory negligence have only a very small impact on the quantum of the award.

124. See above the text accompanying n 98 .

125. See section 3 above.

126. See section 5 above.

127. See section 5(c) above.

128. It has been attacked on other bases: see section 4(a)(i) above.

129. See eg D Manderson and N Sharp 'Mandatory sentences and the constitution: discretion, responsibility, and judicial process' (2000) 22 Sydney L Rev 585.

130. See Ashworth, above n 95, pp 50-54. 
It should also be remembered, in considering the suggestion that fixed reduction rules might interfere with judicial independence, that the discretion that judges enjoy to apportion damages for contributory negligence is itself a product of statutory intervention. At common law, judges had (and still have) no discretion to reduce damages on account of the claimant's fault. ${ }^{131}$ It would thus be rather odd to complain that Parliament, were it to create fixed reduction rules and thereby limit the discretion that it had granted to judges pursuant to the apportionment provision, was intruding on judicial independence.

\section{WIDER IMPLICATIONS: THE LAW OF CONTRIBUTION}

What implications does the analysis in this paper have for the law of torts generally? One part of tort law that needs to be kept in mind in this regard is the law of contribution. Leaving aside the details, which are unimportant for present purposes, legislation in most common-law jurisdictions permits a wrongdoer to recover contribution from any other person who is liable for the same damage. ${ }^{132}$ The assessment of contribution is to be determined according to what the court thinks is 'just and equitable having regard to the extent of [the] responsibility [of the person from whom contribution is sought] for the damage in question'. ${ }^{133}$ This language, which confers significant discretion upon judges, obviously bears a striking similarity to that used in many apportionment statutes. The law of contribution is also in thrall to the discretionary approach. However, just as is the case in relation to the apportionment of damages for contributory negligence, rules that fixed judges' discretion have seeped into the law of contribution too. For example, in England and Wales the Froom rules are applied where a negligent motorist seeks contribution from a parent who negligently failed to secure their infant child properly in their vehicle. ${ }^{134}$ Rules that limit judicial discretion in relation to contribution proceedings also exist in New Zealand. In Carrington v Easton, Venning J, in the High Court of New Zealand, remarked in the context of proceedings in respect of defective premises that the generally accepted allocation of responsibility between [a negligent] builder and [a negligent council that failed in its duty of inspection] was fixed at 80 per cent $/ 20$ per cent. In some cases the Council will have a lesser responsibility. In only the rarest cases will it be more. ${ }^{135}$ This paper has not addressed contribution. However, because the rules that govern the apportionment of damages for contributory negligence and contribution are so similar, the argument that has been offered in relation to contributory negligence would also seem to apply to contribution. The relevant goal, therefore, if the analysis that has been offered in relation to contributory negligence is correct, should be to develop rules that limit judicial discretion in the contribution context too.

131. '[T]he rule of law is that if there is blame causing the accident on both sides, however small that blame may be on one side, the loss lies where it falls': Cayzer, Irvine \& Co v Carron Co (1884) 9 App Cas 873 (HL) 881 (Lord Blackburn).

132. See eg Civil Liability (Contribution) Act 1978.

133. Civil Liability (Contribution) Act 1978, s 2(1).

134. Jones $v$ Wilkins [2001] RTR 19 at [13]-[14] (CA) (parent liable for $25 \%$ of the damages); Hughes v Williams [2013] EWCA Civ 455; [2013] PIQR P17 (same).

135. [2013] NZHC 2023 at [61]. 


\section{CONCLUSION}

The main argument advanced in this paper is that the law on apportionment for contributory negligence is slanted much too far in the direction of discretionary apportionment. Matters would be considerably improved if more fixed apportionment rules were introduced. Because the apportionment legislation is committed to an extreme system of discretionary apportionment, it can plausibly be argued that the landmark case of Froom was decided per incuriam in so far as that decision created fixed apportionment rules, which is what Froom has generally been understood as doing. However, on the analysis that has been presented here, Lord Denning MR, although he arguably acted in defiance of the apportionment legislation, was right to be attracted to a more fixed system of apportionment. 